\title{
Web-Based E-Teylor Sales Indormation System Design
}

\author{
$Y D$ Pramudita, $A F$ Doni*, $S S$ Putro \\ Departement of Informatic Engineering, University of Trunojoyo Madura, Indonesia
}

\begin{abstract}
The design of the E-Tailor sales information system is a web-based application as a means for employees or business owners to make it easier to order clothes online. Websites with this system can provide solutions to owners or tailors and consumers or ordering goods for smooth orders, transactions and completion of ordered goods on time and this will also make it easier for users to be able to order sewing items online without having to come to a tailor shop. In the design here it is also explained how a system will be built and run according to the manufacturing method carried out, for the design of the E-Tailor Information System is presented using UML (Unified Modeling Language). The testing method on the design of the e-tailor information system using the black box method only focuses on input and output that informs the suitability of the application developed with the specified specifications. The test results show that the success rate of the application runs well in accordance with the tests that have been carried out.
\end{abstract}

Keywords: E-Tailor, Unified Modeling Language, Black Box Method

\section{Introduction}

Clothing or clothing is one of the basic human needs. In the current era, the development of fashion is very fast and rapid. Many people choose to get clothes [1]. One of them with sewing services. People are used to ordering sewing services at one of the tailors who have become customers [2]. However, there are obstacles in ordering sewing services directly or manually, namely, having to come to the tailor directly, sometimes there are too many sewing orders for tailors, so the tailor refuses the service. Sometimes when a tailor has a lot of sewing orders, he can't be sure of the completion time of the sewing order [3][4].

People prefer to buy ready-made clothes at malls or clothing stores rather than making clothes to tailors because of the factors mentioned above. Especially in today's increasingly advanced internet, people prefer to buy clothes online because it is more efficient and cheaper [5]. However, sometimes problems arise again, the suitability of clothes seen in online media with clothes that have been purchased is very different, this is detrimental to consumers. Expectations to be expected on the clothes on display are very different[6]. Many online merchants are concerned with quantity rather than the quality of the clothes they sew, because the demand for goods is very large and for the sake of price they are also offered to the market [7]. From the various problems above, it provides an alternative to making online sewing orders that can characterize every consumer or customer. So that customers can choose their own fabric and enter their own size who wants to make costume size clothes or clothes that match the consumer's body size[8].

E-Tailor software is software used for online sewing orders. This system is related to several external entities, namely admin, buyer/customer/user. We named this sewing ordering web application E-TAILOR. This application can login as owner and customer. To log in as the owner, the owner can make orders to add new types of clothes needed, edit clothing details, delete clothing details, delete orders made by customers. To $\log$ in as a customer, the customer can place an order accordingly and the customer can see all the details of the clothes that are in the system, and can also edit the order data [9].

The large number of orders for tailors in the old way has made it difficult for a tailor in Bangkalan to handle the amount of work and time required for the transaction, and it is feared that the order cannot be completed within the allotted time because time is wasted just for negotiating the customer's goods[10]. Therefore, we need a solution that can be a way out to maintain the quality of tailors in Bangkalan. E-Tailor as a means of online ordering system in the field of tailors focuses on completing orders for goods with a technological approach seeking to improve the performance of tailors, especially in the Bangkalan area. A website with this system can provide solutions to the owner / tailor and user / order of goods for smooth orders, transactions and completion of ordered goods on time and this will also make it easier for users to be able to order sewing goods online without having to come to a tailor shop.

\footnotetext{
* Corresponding author : doni.fatah@trunojoyo.ac.id
} 
The purpose of this project is to design an E-Tailor information system where this system is suitable for tailors, in making the system it will be built based on a website and with the PHP HTML programming language[11]. Our target subject has sewing services for men's and women's clothes. This place has an owner who works alone in the sewing process and only accepts offline customers. So, this is very inefficient in doing a business because this owner can take orders for clothes online so that they can have many customers and also be able to develop their business. Therefore, a website was created that can be used to develop its business more broadly through the design of making a website-based E-Tailor information system [12].

\section{Method}

\subsection{System Development Method}

For system development, this research uses the SDLC (Software Development Life Cycle) model [13]. System Development Life Cycle (SDLC) is the process of creating and modifying systems and the models and methodologies used to develop a system. SDLC is also a pattern taken to develop a software system, which consists of the following stages: planning, analysis, design, implementation, testing and maintenance [14] [15].

The system development model is built using the spiral SDLC model in the development of this system. R. Eko Indrajit in his book "Management of Information Systems and Information Technology", states that the development of information systems can be categorized into three major groups. The first group is a project that is the construction of information technology infrastructure networks (starting from the procurement and installation of computers to the planning and development of LAN and WAN network infrastructure) [16][17].

The second group is the implementation of application program packages purchased in the market and implemented in companies, ranging from small software such as Microsoft retail products to integrated applications based on high technology[18]

The third group is the planning and development of specially made applications (customized software), both by internal organizations and in collaboration with external parties, such as consultants and software houses [19].

\subsection{System Design Method}

In designing this E-Tailor Information System, we use UML (Unified Modeling Language). UML is also a way to facilitate continuous application development. Undocumented applications or systems can usually hinder development because developers have to perform searches and study the program code. UML can also be a tool for transferring knowledge about the system or application that will be developed from one developer to another. Not only between developers to business people and anyone can understand a system with UML.

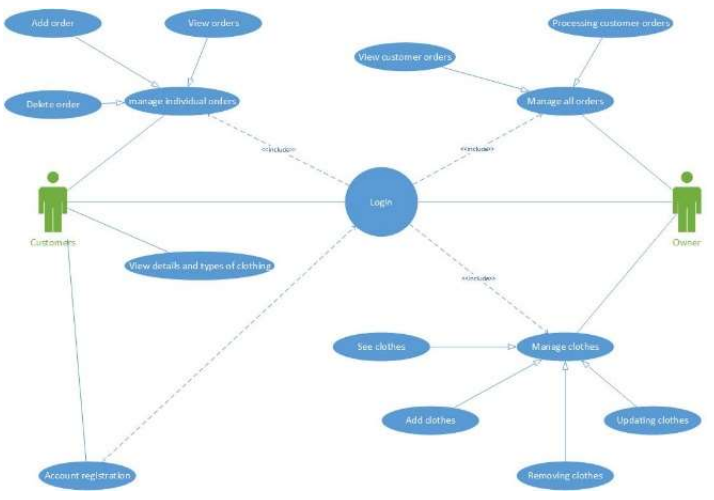

Fig. 1. System design use case

Figure 1 is an illustration of the use case for designing a web-based e-tailor information system to be built. There are several main Use Case names that represent the design of the system that was built starting from: Login, Account registration, viewing types and details of clothes, manage individual orders, manage clothes and manage all orders

\subsection{Data Collection Method}

To create this E-Tailor Information System, we collect data from clients in the form of interviews, analyze the desired needs and use direct observation so that what is needed can be in accordance with what the client or user wants.

\subsection{Test Method}

The black box testing method focuses on the functional requirements of the software. Therefore, black box testing allows software developers to create a set of input conditions that will exercise all the functional requirements of a program [20][21].

The method used in this web test uses the black box method with boundary value analysis techniques. The boundary value analysis technique tests the quality of the web by showing that there are still some errors when entering data to be tested in the column to determine whether the input value is valid or not with a predetermined lower and upper limit. So that the problems that occur can cause the data stored in the database is not in accordance with the expected data. The test is carried out on an e-tailor web form that has input by testing the upper limit value and lower limit value through several predetermined stages for each column contained in the form.

\section{Result and Discussion}

In this test apply black box techniques for the testing process on a web-based e-tailor information system. Testing is done by following the description of the test. The results of these tests are then recorded in the test results column. Based on the test results, you can then determine by adjusting the results of the test and the expected results. If the results tested are in accordance 
with the expected results (there are still obstacles or errors) then the conclusion is successful. If the results tested are not in accordance with the expected results, then the conclusion is a failure.

The testing method taken using the black box technique includes the functionality testing, usibility testing, interface testing, compatibility testing, performance testing, and security testing methods. These methods are used to find out if the software is working properly. In these methods test data is generated, executed on the software and then the output of the software is checked whether it is as expected or not.

For example, the functionality testing method, where in this section there are things that are tested including database connection testing, form testing, especially on forms used for CRUD activities (create, read, update, and delete) on the order menu, login and register pages, Cookie testing, Testing syntax or source code.

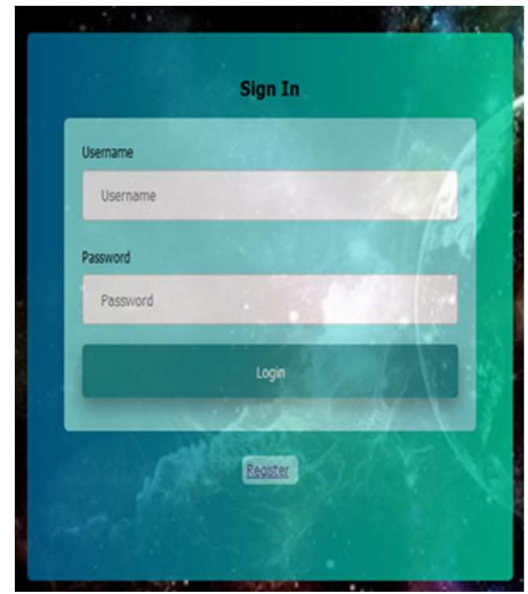

Fig. 2. Testing the login page on a web-based e-tailor information system

In Figure 2 there are 2 inputs. Username input in the form of username receives input in the form of numbers, based on boundary value analysis techniques, examples of valid input values are between $a-z$ \& A-Z while invalid ones are 0-9. Password input accepts input in the form of letters and numbers, based on boundary value analysis techniques, examples of valid input values between a-Z, A-Z and numbers between 0-9. while the invalid ones are $\mathrm{a}-\mathrm{z} \& \mathrm{~A}-\mathrm{Z}$ only or numbers $0-9$ only

Table 1. Test Case Login Form

\begin{tabular}{|l|l|l|l|l|}
\hline $\begin{array}{l}\text { Test } \\
\text { ID }\end{array}$ & Description & $\begin{array}{l}\text { Expected } \\
\text { Results }\end{array}$ & $\begin{array}{l}\text { Test } \\
\text { Results }\end{array}$ & Status \\
\hline & & $\begin{array}{l}\text { The } \\
\text { system } \\
\text { will } \\
\text { display }\end{array}$ & $\begin{array}{l}\text { The system } \\
\text { displays } \\
\text { error } \\
\text { messages }\end{array}$ & \\
CS1 & $\begin{array}{l}\text { Clear all } \\
\text { fields and } \\
\text { press the } \\
\text { login button } \\
\text { message }\end{array}$ & $\begin{array}{l}\text { 'usernam } \\
\text { 'username } \\
\text { is required' } \\
\text { and } \\
\text { required' } \\
\text { and }\end{array}$ & $\begin{array}{l}\text { 'password } \\
\text { is required' }\end{array}$ & \\
& & & & \\
\end{tabular}

\begin{tabular}{|c|c|c|c|c|}
\hline & & $\begin{array}{l}\text { 'passwor } \\
\mathrm{d} \text { is } \\
\text { required' }\end{array}$ & & \\
\hline CS2 & $\begin{array}{l}\text { Fill in the } \\
\text { username } \\
\text { field and } \\
\text { leave the } \\
\text { password } \\
\text { field blank. }\end{array}$ & $\begin{array}{l}\text { The } \\
\text { system } \\
\text { will } \\
\text { display } \\
\text { an error } \\
\text { message } \\
\text { 'passwor } \\
\text { d } \\
\text { required' }\end{array}$ & $\begin{array}{l}\text { System } \\
\text { displays } \\
\text { error } \\
\text { message } \\
\text { 'password } \\
\text { required' }\end{array}$ & Succeed \\
\hline CS3 & $\begin{array}{l}\text { Fill in the } \\
\text { password } \\
\text { field and } \\
\text { leave the } \\
\text { username } \\
\text { field blank. }\end{array}$ & $\begin{array}{l}\text { The } \\
\text { system } \\
\text { will } \\
\text { display } \\
\text { error } \\
\text { messages } \\
\text { 'usernam } \\
\text { e } \\
\text { required' } \\
\text { and } \\
\text { 'passwor } \\
\text { d } \\
\text { required' }\end{array}$ & $\begin{array}{l}\text { The system } \\
\text { displays } \\
\text { error } \\
\text { messages } \\
\text { 'username } \\
\text { required' } \\
\text { and } \\
\text { 'password } \\
\text { required' }\end{array}$ & Succeed \\
\hline CS4 & $\begin{array}{l}\text { Fill in the } \\
\text { username } \\
\text { field with } \\
\text { an incorrect } \\
\text { username } \\
\text { and leave } \\
\text { the } \\
\text { password } \\
\text { blank }\end{array}$ & $\begin{array}{l}\text { The } \\
\text { system } \\
\text { will } \\
\text { display } \\
\text { error } \\
\text { messages } \\
\text { 'your } \\
\text { username } \\
\text { is } \\
\text { incorrect' } \\
\text { and } \\
\text { 'passwor } \\
\text { d } \\
\text { required' }\end{array}$ & $\begin{array}{l}\text { The system } \\
\text { displays } \\
\text { error } \\
\text { messages } \\
\text { 'your } \\
\text { username } \\
\text { is } \\
\text { incorrect' } \\
\text { and } \\
\text { 'password } \\
\text { required' }\end{array}$ & Succeed \\
\hline CS5 & $\begin{array}{l}\text { Fill in the } \\
\text { password } \\
\text { field with } \\
\text { an incorrect } \\
\text { password } \\
\text { and leave } \\
\text { the } \\
\text { username } \\
\text { field blank }\end{array}$ & $\begin{array}{l}\text { The } \\
\text { system } \\
\text { will } \\
\text { display } \\
\text { error } \\
\text { messages } \\
\text { 'your } \\
\text { password } \\
\text { is } \\
\text { incorrect' } \\
\text { and } \\
\text { 'usernam } \\
\text { e is } \\
\text { required' }\end{array}$ & $\begin{array}{l}\text { The system } \\
\text { displays } \\
\text { error } \\
\text { messages } \\
\text { 'your } \\
\text { password } \\
\text { is } \\
\text { incorrect' } \\
\text { and } \\
\text { 'username } \\
\text { required' }\end{array}$ & Succeed \\
\hline CS6 & $\begin{array}{l}\text { Fill in the } \\
\text { username } \\
\text { field with } \\
\text { an incorrect } \\
\text { username } \\
\text { and fill in } \\
\text { the } \\
\text { password } \\
\text { field with } \\
\text { an incorrect } \\
\text { password }\end{array}$ & $\begin{array}{l}\text { The } \\
\text { system } \\
\text { will } \\
\text { display } \\
\text { error } \\
\text { messages } \\
\text { 'your } \\
\text { username } \\
\text { is } \\
\text { incorrect' } \\
\text { and 'your } \\
\text { password } \\
\text { is } \\
\text { incorrect' }\end{array}$ & $\begin{array}{l}\text { incorrect' } \\
\text { and 'your } \\
\text { password } \\
\text { is } \\
\text { incorrect' } \\
\text { The system } \\
\text { displays } \\
\text { error } \\
\text { messages } \\
\text { 'your } \\
\text { username } \\
\text { is } \\
\text { incorrect' } \\
\text { and 'your } \\
\text { password } \\
\text { is } \\
\text { incorrect' }\end{array}$ & Succeed \\
\hline
\end{tabular}




\begin{tabular}{|c|c|c|c|c|}
\hline CS7 & $\begin{array}{l}\text { Fill in the } \\
\text { username } \\
\text { field with } \\
\text { the correct } \\
\text { username } \\
\text { and fill in } \\
\text { the } \\
\text { password } \\
\text { field with } \\
\text { the wrong } \\
\text { password. }\end{array}$ & $\begin{array}{l}\text { The } \\
\text { system } \\
\text { will } \\
\text { display } \\
\text { an error } \\
\text { message } \\
\text { 'Your } \\
\text { password } \\
\text { is } \\
\text { incorrect' }\end{array}$ & $\begin{array}{l}\text { The system } \\
\text { will } \\
\text { display an } \\
\text { error } \\
\text { message } \\
\text { 'Your } \\
\text { password } \\
\text { is } \\
\text { incorrect' }\end{array}$ & Succeed \\
\hline CS8 & $\begin{array}{l}\text { Fill in the } \\
\text { username } \\
\text { field with } \\
\text { the correct } \\
\text { username } \\
\text { and fill in } \\
\text { the } \\
\text { password } \\
\text { field with } \\
\text { the correct } \\
\text { password. }\end{array}$ & $\begin{array}{l}\text { The } \\
\text { system } \\
\text { will } \\
\text { display } \\
\text { the start } \\
\text { page of } \\
\text { the web- } \\
\text { based e- } \\
\text { tailor } \\
\text { informati } \\
\text { on } \\
\text { system }\end{array}$ & $\begin{array}{l}\text { The system } \\
\text { displays } \\
\text { the start } \\
\text { page of a } \\
\text { web-based } \\
\text { e-tailor } \\
\text { informatio } \\
\text { n system }\end{array}$ & Succeed \\
\hline
\end{tabular}

\section{Conclusion}

Based on the tests that have been carried out using the black box method including functionality testing, usability testing, interface testing, compatibility testing, performance testing, and security testing methods. It can be concluded that testing on a web-based e-tailor information system which in the example tested the login page that informed the suitability of the developed application with predetermined specifications. The test results show that the success rate of the application runs well.

\section{References}

[1] R. Alanezi, M. A. Alanezi, and N. A. Khan, "Development of Web Based E-Cooperative Training System," 2018 Int. Conf. Smart Comput. Electron. Enterp. ICSCEE 2018, pp. 16, (2018), doi: 10.1109/ICSCEE.2018.8538367.

[2] R. Rastogi and R. Von Solms, "Information security service branding - Beyond information security awareness," IMSCI 2011 - 5th Int. MultiConference Soc. Cybern. Informatics, Proc., vol. 1, no. 6, pp. 55-60, (2011).

[3] S. E. Hatane, "Developing a Web-Based Information System for Publishing and Printing Enterprise," no. June, pp. 1-6, (2011).

[4] M. Dukaczewski, D. Reiss, M. Stein, and B. Rumpe, "MontiWeb-Modular Development of Web Information Systems," Proc. 9th OOPSLA Work. Domain-Specific Model. (DSM “ 09), no. October, (2009), [Online]. Available: http://www.se-rwth.de/publications/MontiWebModular-Development-of-Web-InformationSystems.pdf.

[5] B. Hariadi, M. J. D. Sunarto, and P. Sudarmaningtyas, "Development of Web-Based Learning Application for Generation Z," Int. J. Eval. Res. Educ., vol. 5, no. 1, p. 60, (2016), doi: 10.11591/ijere.v5i1.4523.

[6] A. F. Doni, F. A. Mufarroha, Y. D. P. Negera, and E. Sugiarti, "Development of Web Based Information System for Branding Services," IOP Conf. Ser. Mater. Sci. Eng., vol. 1125, no. 1, p. 012051, (2021), doi: 10.1088/1757$899 \mathrm{x} / 1125 / 1 / 012051$.

[7] J. P. Queiroz and B. Oliveira, "Benefits of the Marketing Information System in the Clothing Retail Business," J. Inf. Syst. Technol. Manag., vol. 11, no. 1, pp. 153-168, (2014), doi: 10.4301/s1807-17752014000100009.

[8] M. Singh, "Product Quality for Competitive Advantage In Marketing," Int. J. Bus. Manag. Invent., vol. 2, no. 6, pp. 05-08, (2013), [Online]. Available:

http://www.ijbmi.org/papers/Vol(2)6/Version2/B02620508.pdf.

[9] B. Liu and W. Liu, "Web based management information system development and design - By the old and the new system of rural society endowment insurance connection as an example," Adv. Mater. Res., vol. 664, pp. 10601065, (2013), doi: 10.4028/www.scientific.net/AMR.664.1060.

[10] I. Soesanti, "Design and development of WebBased Information System for The Batik Industry," IPTEK J. Proc. Ser., vol. 0, no. 1, (2015), doi: 10.12962/j23546026.y2014i1.388.

[11] L. Astuti, Y. Wihardi, and D. Rochintaniawati, "The Development of Web-Based Learning using Interactive Media for Science Learning on Levers in Human Body Topic," J. Sci. Learn., vol. 3, no. 2, pp. 89-98, (2020), doi: 10.17509/jsl.v3i2.19366.

[12] M. Renee Garett, MS, LCSW, Jason Chiu, MS, Ly Zhang, Sean D. Young, PhD, "A Literature Review: Website Design and User Engagement Renee," Online J Commun Media Technol, vol. 46, no. 5, pp. 1247-1262, (2017), doi: 10.1002/jmri.25711.PET/MRI.

[13] M. Younas, D. N. A. Jawawi, I. Ghani, and R. Kazmi, "Non-Functional Requirements Elicitation Guideline for Agile Methods," $J$. Telecommun. Electron. Comput. Eng., vol. 9, no. 3-4 Special Issue, pp. 137-142, (2017).

[14] M. O. Faruque et al., "Real-Time Simulation Technologies for Power Systems Design, Testing, and Analysis," IEEE Power Energy Technol. Syst. J., vol. 2, no. 2, pp. 63-73, (2015), doi: 10.1109/JPETS.2015.2427370.

[15] I. T. Handoyo and D. I. Sensuse, "A review of web-based information system for decision support context," Proc. 11th Int. Conf. Inf. Commun. Technol. Syst. ICTS 2017, vol. 2018Janua, pp. 275-280, (2018), doi: 10.1109/ICTS.2017.8265683.

[16] D. Lopes-Teixeira, F. Batista, and R. Ribeiro, "Spatio-temporal analysis of brand interest using social networks," Iber. Conf. Inf. Syst. Technol. Cist., vol. 2018-June, pp. 1-6, (2018), doi: 10.23919/CISTI.2018.8399241.

[17] J. dos Santos, L. E. G. Martins, V. A. de Santiago 
Júnior, L. V. Povoa, and L. B. R. dos Santos, "Software requirements testing approaches: a systematic literature review," Requir. Eng., (2019), doi: 10.1007/s00766-019-00325-w.

[18] M. Ismail, W. Z. A. Mokhtar, N. N. M. Nasir, N. R. L. Rashid, and A. K. Ariffin, "The development of a web-based homework system (WBH) Via TCExam," Mediterr. J. Soc. Sci., vol. 5, no. 15, pp. 249-255, (2014), doi: 10.5901/mjss.2014.v5n15p249.

[19] E. Oktaviani, U. Cahyana, and A. Purwanto, "Development of Web-Based Chemical Learning Media in Coloid System Topic Using Wordpress," JTK (Jurnal Tadris Kim., vol. 5, no. 1, pp. 104-117, (2020), doi: 10.15575/jtk.v5i1.7425.

[20] F. Z. Hammani, "Survey of Non-Functional Requirements modeling and verification of Software Product Lines," Proc. - Int. Conf. Res. Challenges Inf. Sci., (2014), doi: 10.1109/RCIS.2014.6861085.

[21] A. Bouain, A. El Fazziki, and M. Sadgal, "Integration of non-functional requirements in a service-oriented and model-driven approach," Proc. - Int. Conf. Res. Challenges Inf. Sci., (2014), doi: 10.1109/RCIS.2014.6861058. 